\title{
Peningkatan Kapasitas Usaha Mina Mandiri Melalui Pelatihan Pemasaran Produk Olahan Ikan
}

\author{
Amalia Nadifta Ulfa, Umi Barokah", Darsono, Rhina Uchyani Fajarningsih, Joko Sutrisno, \\ dan Suprapti Supardi
}

Program Studi Agribisnis, Fakultas Pertanian, Universitas Sebelas Maret

Jl. Ir. Sutami No 36 A Kentingan Surakarta

*Corresponding Author: amalia.nadifta@staff.uns.ac.id

\begin{abstract}
ABSTRAK
Pendapatan yang diperoleh dari pekerjaan utama sebagai petani padi belum mampu mencukupi kebutuhan keluarga petani Desa Sindumartani, Ngemplak, Sleman. Untuk itu penduduk memanfaatkan sebagian lahan untuk budidaya ikan nila. Ternyata dari usaha budidaya ikan nila belum memberikan tambahan pendapatan yang signifikan. Hal ini dikarenakan petani memasarkan ikan segar dengan teknik sederhana (konvensional) dengan lingkup yang terbatas. Kelompok Tani Ikan Mina Mandiri dituntut untuk lebih kreatif menetapkan strategi pemasaran sehingga produknya lebih dikenal, diminati konsumen dan menjangkau pasar lebih luas. Untuk itu sangat diperlukan pelatihan pemasaran guna meningkatkan kapasitas usahanya. Upaya memasarkan dengan menggabungkan strategi offline dan online strategi. Pengabdian ini dilakukan dalam rangka memberikan pelatihan pemasaran. Adanya pelatihan pemasaran ini mampu memberikan pengetahuan pemasaran yang tepat untuk produk olahan ikan nila, sehingga dapat memperluas wilayah pemasaran dan meningkatkan kapasitas usaha kelompok.
\end{abstract}

Kata kunci: pemasaran, olahan ikan nila, kelompok tani ikan

\section{ABSTRACT}

The income earned from the main job as a rice farmer has not been able to meet the needs of a farmer family in Sindumartani Village, Ngemplak, Sleman. Residents use some of the land for tilapia farming. Tilapia aquaculture business has not provided significant additional revenue. Farmers market fresh fish with simple techniques (conventional) with a limited scope. Mina Mandiri Fish Farmers Group is required to be more creative in setting marketing strategies so that their products are better known, interested in consumers and reach a wider market. Farmer groups need marketing training to increase their business capacity. Market efforts by combining offline strategies and online strategies. This service is carried out in order to provide marketing training. The existence of this marketing training provides the right marketing knowledge for fish processed products, so that it can increase the marketing area and increase the group's business capacity.

Keywords: marketing, processed fish, fish farmer groups

\section{PENDAHULUAN}

Mayoritas penduduk Desa Sindumartani, Kecamatan Ngemplak, Kabupaten Sleman adalah petani dengan komoditas utama padi yang mana pendapatannya dipengaruhi oleh harga beras, pendidikan, pendapatan off-farm (non-pertanian) dan asset yang dimiliki oleh rumah tangga petani (Antriyandarti \& Fukui, 2010). Sebagaimana yang telah dikemukakan oleh Godoy \& Dewbre (2010) dan Babatunde \&
Qaim (2009) bahwa off-farm jobs berperan penting dalam mengurangi kemiskinan di pedesaan karena petani berskala kecil dapat meningkatkan pendapatan rumah tangga. Pendapatan dari usahatani padi mempunyai kontribusi sangat kecil dalam pendapatan rumah tangga karena sempitnya lahan yang digarap (0,3278 ha), sehingga kurang mencukupi untuk kebutuhan sehari-hari secara layak. Beberapa kepala keluarga (hanya sekitar $12 \%$ saja) mempunyai pekerjaan sampingan non-pertanian 
(off-farm jobs) untuk menambah pendapatan keluarga (Antriyandarti, 2016). Ditambah dengan kondisi saluran irigasi yang masih semiteknis, menjadikan produktivitas padi di Desa Sindumartani tidak optimal dan tidak efisien serta berdaya saing (Antriyandarti, 2015).

Ilmu pemasaran yang terus berkembang sampai saat ini masih merupakan pengembangan konsep pemasaran yang fondasi awalnya dikembangkan oleh Philip Kotler yang dikenal 4P pilar pemasaran Kotler, atau dikembangkan lagi sebagai $7 P$ Kotler marketing concept. $\mathrm{Ke}$ tujuh konsep yang dimaksud meliputi: (1) Product, (2) Price, (3) Place, (4) Promotion, (5) People, (6) Process, dan (7) Physical Evident. Terkait konsep pemasaran, dari ke 7 elemen atau pilar pemasaran pengusaha dapat melakukan upgrading atau pembenahan sistem usahanya agar lebih mudah untuk memulai melakukan pendekatan strategi yang dapat ditonjolkan.

Strategi bisnis terkait dengan kondisi yang sedang dihadapi, bahkan untuk perusahaan yang mantap sudah melakukan peramalan (forecasting) melalui serangkaian data untuk prediksi bersifat longrun term. Konsep pemasaran berbeda dengan sekedar penjualan atau selling yang selama ini sudah dilakukan oleh kelompok usaha di Desa Sindumartani. Guna memfasilitasi ibu-ibu rumah tangga untuk memasarkan usaha aneka pangan olahan dengan bahan baku yang tersedia melimpah di desa tersebut dilakukan pengabdian berupa pelatihan pemasaran produk olahan ikan.

Program pengabdian ini bertujuan untuk meningkatkan kapasitas usaha kelompok Sindumartani ini dengan melakukan kegiatan pelatihan pemasaran produk secara online dan offline untuk meningkatkan skill bisnis, sehingga dapat meningkatkan kapasitas usaha melalui peningkatan skill dan knowledge SDM serta penggunaan teknologi tepat guna.

\section{METODE}

Kegiatan pengabdian dilaksanakan di Desa Sindumartani, Kecamatan Ngemplak, Kabupaten Sleman. Kegiatan ini melibatkan ibuibu dalam Program Kemitraan Masyarakat (PKM) dengan menggunakan metode Participatory Rural Appraisal (PRA). Menurut Cavestro (2003) PRA adalah suatu metode yang menempatkan masyarakat sebagai subyek, perencana, pelaksana, sekaligus sebagai penilai dalam program pemberdayaan sehingga tim pengabdian dan stakeholder yang terlibat sebagai fasilitator dan masyarakat sebagai pelakunya. Pengabdian dilaksanakan setelah pencarian informasi mengenai masalah, kebutuhan dan potensi yang ada di desa. Partisipasi berarti masyarakat terlibat dalam proses pendekatan "bottom-up" yang menuntut kemampuan berkomunikasi yang baik dan teknologi yang ditransfer dapat digunakan dalam situasi apapun.

Partisipasi dalam pengabdian ini merujuk pada 3 (tiga) definisi, pertama: partisipasi didefinisikan sebagai gerakan masyarakat untuk terlibat dalam proses pembuatan keputusan, dalam pelaksanaan kegiatan, ikut menikmati hasil kegiatan, dan ikut serta mengevaluasinya (Uphoff, 1988), kedua: partisipasi dianggap sebagai proses dimana berbagai pelaku dapat mempengaruhi serta membagi wewenang dalam menentukan inisiatif-inisiatif pembangunan, serta keputusan serta pengalokasian berbagai sumber daya yang berpengaruh terhadap kehidupan mereka (World Bank, 2004).

Pelatihan kegiatan pemasaran dilakukan melalui 4 tahap, dengan rincian sebagai berikut:

1. Tahap pertama dilakukan dengan cara menetapkan strategi pemasaran dan membuat target bisnis, kegiatan ini dilakukan dengan penentuan strategi pemasaran yang hendak dilakukan berdasarkan produk yang hendak dipasarkan.

2. Tahap kedua dilakukan dengan identifikasi pesaing, target konsumen, dan diferensiasi produk.

3. Tahap ketiga dilakukan dengan promosi secara online dan offline.

4. Tahap keempat dilakukan dengan mengembangkan peningkatan sales, membangun merek, dan melengkapi legalitas izin usaha.

Kegiatan awal dilakukan dengan perhitungan harga pokok produksi untuk mengetahui harga awal dari produk yang telah dihasilkan. Selanjutnya, akan diberikan materi berupa manajemen pemasaran. Menurut Kotler \& Armstrong (2012) manajemen pemasaran sebagai seni dan ilmu memilih pasar sasaran dan mendapatkan, mempertahankan, serta meningkatkan jumlah pelanggan dengan menciptakan, menghantarkan dan mengkomunikasikan nilai pelanggan yang unggul. Dalam bauran pemasaran terdapat seperangkat alat pemasaran yang dikenal dalam istilah 4P, yaitu product (produk), price (harga), place (tempat atau saluran distribusi), dan promotion (promosi). Kondisi yang dibahas 
terkait dengan beberapa hal, yang menurut Kotler \& Keller (2012) dalam pemasaran meliputi 4P. Pada pendekatan 4C, perlu dilakukan marketing research dan analisis dari mulai mengidentifikasi demografi (gender, usia, pendapatan, pendidikan, lokasi, status pernikahan, dan budaya) hingga psikografi (gaya hidup, kepribadian). Hal ini merupakan fundamental dalam rangka mengenal lebih dekat dan bagaimana mendekati target market (Kotler \& Keller, 2012; Wijayanti, 2012). 4P kemudian berkembang menjadi $7 \mathrm{P}$, yang dikenal dengan bauran pemasaran (marketing mix).

1. Product. meliputi kualitas, rasa, nutrisi, tampilan, tanggal kedaluwarsa, processing dan kemasan. Produk terdiri dari 3 bagian utama yaitu inside of produk, outside of product, dan brand atau merk. Inside of produk atau melihat sisi produk dari dalamnya, produk makanan minimal memiliki sifat yang melekat yaitu, enak, bergizi, dan menarik. Sifat isi produk tersebut mudah dideteksi atau diketahui dengan membandingkan sifat isi produk milik pesaing. Outside of product adalah identitas produk dari sisi tampilan luar sebuah produk yang meliputi tampilan yang menarik, eye catching, dan mewakili karakter produk. Dari sisi tampilan luar, sebuah produk yang baik akan selalu mudah dan menarik untuk dibedakan dengan produk lainnya. Sedangkan dari sisi merk, sebuah produk harus memiliki sebutan yang mudah diingat serta mudah diucapkan atau sederhana dalam penyebutan dan mudah diingat. Jika dari sisi ketiga bagian produk sudah dapat diandalkan, maka dapat dikatakan produk tersebut handal atau unggul.

2. Price. Harga merupakan nilai akan suatu produk yang dikenakan oleh manajemen yang harus memiliki nilai keterwakilan terhadap produk dan daya saing terhadap kompetitor. Perhitungan harga mengacu kepada besarnya harga pokok produksinya (HPP) ditambah dengan besaran laba yang dikehendaki. Perhitungan harga pokok produksi dilakukan untuk mengetahui harga dasar penjualan agar memperoleh laba sesuai yang diharapkan.

3. Promotion. Dalam aktivitas promosi yang dilakukan, menggunakan metode yang dapat dilakukan meliputi: Face to face negotiation atau negosiasi melalui tatap muka; Social Media yaitu semua aktivitas promosi yang dilakukan melalui gadget atau menggunakan jaringan internet; direct selling, atau penjualan secara langsung melalui pameran atau even-even yang mendatangkan masa; dan Social Communication dengan menggunakan stiker, SMS, dan tatap muka.

4. Place. Terkait dengan saluran distribusi fisik diantaranya meliputi jumlah dan kestrategisan tempat. Tempat dapat berupa outlet, warung cabang, tempat produksi, dan lain-lain. Tempat produksi melipui tempat yang bersih, nyaman, dan terjangkau. Sedangkan tempat berjualan meliputi: tempat yang berpindah-pindah atau mobile, tempat yang permanen, dan tempat rekanan bisnis atau mitra.

5. People. Meliputi semua orang yang memainkan peran dalam pelayanan dan hal tersebut mempengaruhi persepsi pembeli, yang digambarkan dalam perilaku: keramahan, kesopanan, dan cekatan.

6. Process. Adalah prosedur nyata, mekanisme dan aliran aktivitas dalam pelayanan terhadap konsumen dan sistem operasi, meliputi: keluwesan, aksesibilitas, kepraktisan sebuah sistem. Sistem yang ribet atau bertele-tele akan membuat konsumen jenuh.

7. Physical Evidence. Yaitu lingkungan yang mana layanan dikirimkan dan dimana perusahaan dan pelanggan berinteraksi, serta komponen lain yang tidak terlihat yang memfasilitasi penyampaian pelayanan. Bentuk sarana fisik merupakan hal nyata yang turut mempengaruhi keputusan konsumen untuk membeli dan menggunakan produk atau jasa yang ditawarkan. Unsur yang termasuk dalam sarana fisik antara lain: lingkungan atau bangunan fisik, peralatan, perlengkapan, logo, warna dan barangbarang lainnya.

\section{HASIL DAN PEMBAHASAN}

Objek pengabdian masyarakat merupakan kelompok usaha bersama ibu-ibu yang telah produktif mengusahakan makanan olahan yang berbahan baku ikan budidaya air tawar. Gambaran sekilas mengenai skala usaha tercermin dari omzet bulanan yang mencapai kurang lebih $\mathrm{Rp}$ 3.000.000,00. Mempertimbangkan potensi yang dimiliki berupa melimpahnya sumber bahan baku yang ditunjang oleh lingkungan alam sekitar, serta profil anggota kelompok yang tergolong terdidik kondisi usaha yang saat ini belum optimal masih sangat memungkinkan untuk ditingkatkan atau 
diupgrade ke arah optimalisasi usaha, salah satunya melalui kegiatan pemasaran.

Kegiatan pengabdian dilaksanakan pada tanggal 5 Agustus 2019 di Desa Sindumartani, Kecamatan Ngemplak, Kabupaten Sleman. Sasaran utama dari kegiatan ini adalah warga desa terutama ibu-ibu untuk berpartisipasi aktif dalam Program Kemitraan Masyarakat (PKM). Kegiatan ini bertujuan untuk meningkatkan kapasitas usaha Kelompok Sindumartani dilakukan dengan kegiatan pelatihan pemasaran produk secara online dan offline untuk meningkatkan skill bisnis sehingga meningkatkan kapasitas usaha melalui peningkatan skill dan knowledge SDM serta penggunaan teknologi tepat guna.

Seiring dengan perkembangan era digital, Kelompok Sindumartani tidak lagi dapat bergantung hanya kepada produknya saja namun kepada konsumen. Oleh karena itu, kegiatan ini berupa pelatihan pemasaran produk baik secara online maupun offline. Pelatihan kegiatan pemasaran dilakukan melalui 4 tahap, dengan rincian sebagai berikut:

1. Tahap pertama dilakukan dengan cara menetapkan strategi pemasaran dan membuat target bisnis, kegiatan ini dilakukan dengan penentuan strategi pemasaran yang hendak dilakukan berdasarkan produk yang hendak dipasarkan. Strategi pemasaran yang digunakan adalah mengutamakan pemasaran secara offline dari mulut ke mulut untuk meningkatkan kesadaran masyarakat akan keberadaan produk. Target bisnis ditetapkan berdasarkan data penjualan di Kelompok Sindumartani selama satu tahun terakhir untuk kemudian dirumuskan peningkatannya setiap tahun. Penentuan target bisnis yang utama adalah ibu-ibu karena ibu-ibu merupakan anggota keluarga yang memberikan keputusan terhadap konsumsi rumah tangga, sehingga sesuai dengan target pasar.
2. Tahap kedua dilakukan dengan identifikasi pesaing, target konsumen, dan diferensiasi produk. Di wilayah Kabupaten Sleman belum banyak yang mengembangkan produk yang sama, sehingga tingkat persaingannya relatif rendah. Target utama konsumen adalah ibu rumah tangga sebagai pengambil keputusan konsumsi dalam keluarga, sebagai contoh produk nugget dan bakso ikan yang memiliki kandungan protein guna memenuhi kebutuhan protein anggota keluarga, sehingga produk yang dipasarkan dapat sesuai dengan jenis produk yang dibutuhkan oleh pasar.

3. Tahap ketiga dilakukan dengan promosi secara online dan offline. Promosi secara online merupakan promosi yang memanfaatkan media online (seperti sosial media, dll) hingga produk sampai ke konsumen, sedangkan promosi secara offline merupakan promosi yang menggunakan media offline (seperti media cetak) sehingga produk dapat dikenal oleh masyarakat. Promosi yang telah dilakukan di Kelompok Sindumartani secara online dilakukan melalui website, online shop, dan sosial media seperti: instagram dan facebook. Sedangkan promosi secara offline yang dilakukan oleh Kelompok Sindumartani yaitu dengan membuat brosur, leaflet, serta sponsorship suatu kegiatan.

4. Tahap keempat atau tahap terakhir yang dilakukan adalah dengan mengembangkan peningkatan sales, membangun merek, dan melengkapi legalitas izin usaha. Merek yang digunakan oleh Kelompok Sinduartani disesuaikan dengan jenis makanan olahan yang dibuat, ditambah dengan tulisan 'Sindumartani' sebagai identitas tempat produksi secara spesifik. Terkait legalitas usaha, direncanakan untuk membuat izin usaha seperti: SIUP agar produk yang dipasarkan meyakinkan untuk dipasarkan.

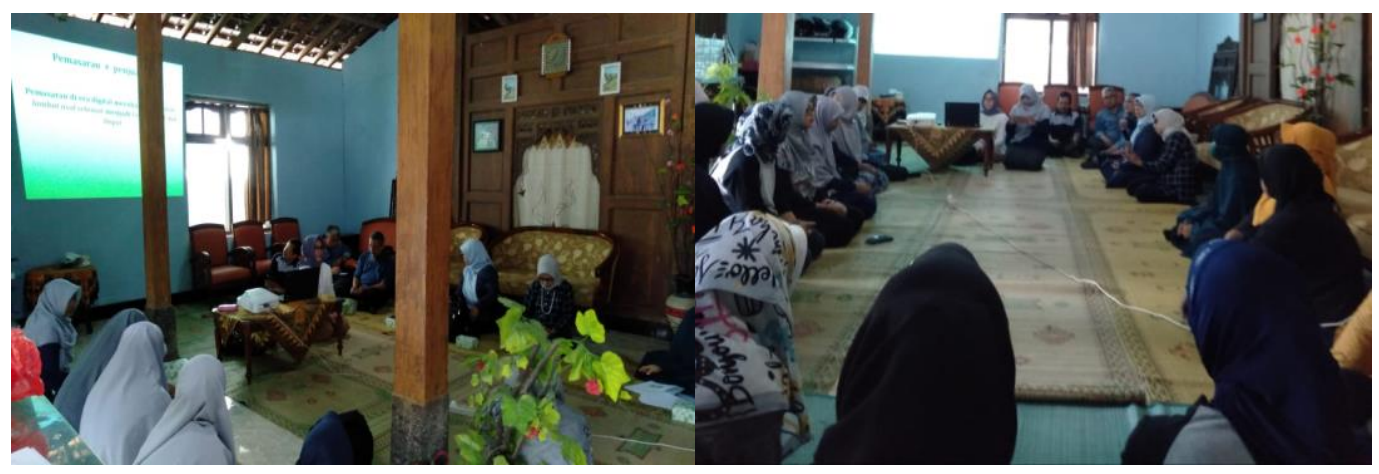

Gambar 1. Kegiatan Pelatihan Pemasaran 
Kegiatan diawali dengan pelatihan berupa cara perhitungan harga pokok produksi (Gambar 1). Perhitungan harga pokok produksi dilakukan untuk mengetahui harga dasar penjualan agar memperoleh laba sesuai yang diharapkan. Perhitungan harga pokok produksi sangat penting untuk keberlanjutan usaha agar mampu berjalan dengan baik pada kondisi apapun. Selain itu diberi materi mengenai teknik-teknik pemasaran yang efektif dan efisien sehingga masyarakat setempat akan memiliki keterampilan dalam memasarkan produk yang dihasilkan. Selanjutnya diberikan materi berupa manajemen pemasaran. Bauran pemasaran yang digunakan dalam kegiatan pengabdian ini menggunakan prinsip $7 \mathrm{P}$, dengan uraian sebagai berikut:

1. Product. meliputi kualitas, rasa, nutrisi, tampilan, tanggal kedaluwarsa, processing dan kemasan. Produk yang dihasilkan oleh Kelompok Sindumartani adalah nugget ikan, kerupuk ikan, dan bakso ikan. Pada bagian kemasan, telah dituliskan merek, komposisi, perusahaan yang memproduksi, serta tanggal kedaluwarsanya, sehingga memudahkan konsumen untuk mengetahui informasi mengenai produk.

2. Price. Perhitungan harga oleh Kelompok Sindumartani mengacu kepada besarnya harga pokok produksinya (HPP) ditambah dengan besaran laba yang dikehendaki. Perhitungan harga pokok produksi dilakukan untuk mengetahui harga dasar penjualan agar memperoleh laba sesuai yang diharapkan. Pada saat kegiatan pengabdian dilakukan, hanya sampai kepada tahap perhitungan harga pokok produksi untuk menginventaris komponen biaya yang dibutuhkan untuk memproduksi produk olahan. Penetapan harga jual disesuaikan dengan besaran laba yang dikehendaki berdasarkan kesepakatan anggota kelompok.

3. Promotion. Promosi yang telah dilakukan di Kelompok Sindumartani secara online dilakukan melalui website, online shop, dan sosial media seperti: instagram dan facebook. sedangkan promosi secara offline yang dilakukan oleh Kelompok Sindumartani yaitu dengan membuat brosur, leaflet, serta sponsorship suatu kegiatan.

4. Place. Terkait dengan saluran distribusi fisik diantaranya meliputi jumlah dan kestrategisan tempat. Tempat dapat berupa outlet, warung cabang, tempat produksi, dan lain-lain. Tempat produksi yang digunakan oleh anggota kelompok selama ini berada di rumah salah satu anggota yang letaknya berdekatan dengan outlet, sehingga memudahkan dalam melakukan transfer produk antara tempat produksi ke tempat penjualan. Tempat penjualan yang tersedia sudah dilengkapi dengan meja, kursi, dan etalase untuk menampilkan sampel produk yang dijual.

5. People. Meliputi semua orang yang memainkan peran dalam pelayanan dan hal tersebut mempengaruhi persepsi pembeli, yang digambarkan dalam perilaku: keramahan, kesopanan, dan cekatan. Anggota kelompok telah dilatih untuk selalu membudayakan 5S ketika berhadapan dengan pelanggan, yaitu dengan Senyum, Salam, Sapa, Sopan dan Santun. Hal ini akan membuat konsumen merasa nyaman untuk membeli produk yang telah dipasarkan.

6. Process. Adalah prosedur nyata, mekanisme dan aliran aktivitas dalam pelayanan terhadap konsumen dan sistem operasi, meliputi: keluwesan, aksesibilitas, kepraktisan sebuah sistem. Tahapan proses untuk memproduksi hasil olahan ikan tawar sudah melalui petunjuk produksi yang ringkas dan efisien karena berbahan baku yang relatif sama, sehingga semua anggota kelompok dapat secara mudah memproduksi hasil olahan ikan sesuai dengan prosedur pembuatan yang telah dirancang.

7. Physical Evidence. Yaitu lingkungan yang mana layanan dikirimkan dan dimana perusahaan dan pelanggan berinteraksi, serta komponen lain yang tidak terlihat yang memfasilitasi penyampaian pelayanan. Sarana fisik di Desa Sindumartani sudah memadai dan layak karena sudah dilengkapi dengan alat-alat yang mendukung untuk memproduksi dan memasarkan produk olahan yang dihasilkan.

\section{KESIMPULAN}

Kegiatan pengabdian yang dilakukan di Kelompok Sindumartani mampu memberikan pengetahuan tentang pemasaran yang tepat bagi produk yang dihasilkan. Hal ini dapat memperluas wilayah pemasaran sehingga pada akhirnya mampu meningkatkan kapasitas usaha mitra. Beberapa kegiatan pemasaran yang dilakukan oleh Kelompok Sindumartani sebagai salah satu bentuk penerapan strategi pemasaran antara lain: (a) mendistribusikan produk dengan menjual melalui pusat oleh-oleh di Kabupaten 
Sleman dan sekitarnya. (b) konsinyasi, yaitu dengan memproduksi produk olahan ikan air tawar dan menitipkannya di toko kelontong yang memadai, dan di BUMDes (Badan Usaha Masyarakat Desa) Desa Sindumartani (c) delivery order (pesan antar), untuk pembelian minimal sejumlah kemasan sesuai yang disepakati. Pemesanan Delivery Order ini dapat dilakukan via SMS, telepon atau online melalui media sosial.

\section{DAFTAR PUSTAKA}

Antriyandarti, E. (2015). Competitiveness and Cost Efficiency of Rice Farming in Indonesia. Journal of Rural Problems, $51(2)$, 74-85. https://doi.org/10.7310/arfe.51.74

Antriyandarti, E. (2016). An Economic Study of the Indonesian Rice Sector: Toward Harmonization of Structural Adjustment and Food Security. Kyoto University, Japan.

Antriyandarti, E., \& Fukui, S. (2010). Impact of Rice Trade Liberalization on Farm Households In Central Java. SEPA, 7(1), 23-29.

Babatunde, R., \& Qaim, M. (2009). The Role of Off-farm Income Diversification in Rural Nigeria: Driving Forces and Household Access. CSAE Conference on Economic Development in Africa. Retrieved from http://www.csae.ox.ac.uk/conferences/20 09-EDiA/papers/051-Babatunde.pdf

Cavestro, L. (2003). P.R.A-Participatory Rural Appraisal Concepts Methodologies and Techniques. Padova PD, Italia: Padova University.

Godoy, D. C., \& Dewbre, J. (2010). Economic Importance of Agriculture for Sustainable Development and Poverty Reduction: Findings from a Case Study of Indonesia. Global Forum on Agriculture 29-30, November 2010, Policies for Agricultural Development, Poverty Reduction and Food Security. Retrieved from http://www.oecd.org/agriculture/agricultu ral-policies/46341215.pdf

Kotler, P., \& Armstrong, G. (2012). Principles of Marketing. New Jersey: Prentice Hall.

Kotler, P., \& Keller, K. L. (2012). Marketing Management. 14th Edition. United States of America: Pearson.

Uphoff, N. (1988). Menyesuaikan Proyek pada Manusia” dalam Mengutamakan Manusia di dalam Pembangunan (Publikasi; M. M. Cernea, Ed.). Jakarta: UI Press.

Wijayanti, T. (2012). Management Marketing Plan. Jakarta: Elex Media Komputindo.

World Bank. (2004). Strategic Framework for Assistance to Africa. Washington: The World Bank. 